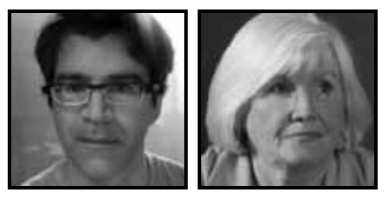

\title{
Mind, Brain, and Education: The Birth of a New Science
}

\section{Michel Ferrari \& Hazel McBride, University of Toronto|OISE}

\section{ABSTRACT}

In this paper, we examine the history of the emerging discipline of Mind, Brain, and Education (MBE) and explore the benefits as well as the difficulties involved in integrating neuroscience into educational policy and practice. We examine the power of neuroscience to impact practice and document the rise of neuromyths. History is on the side of the new discipline of MBE, but there is still much important work to be done to make neuroscientific findings accessible, comprehensible, and relevant to educators.

\section{Part 1. A History of a New Field}

\section{Education in the Ancient World and Europe}

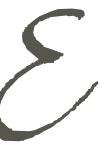

arly written records show that formal education began in Egypt some time between 3000 and 500 B.C.E. Although it is impossible to establish an exact dating, the earliest accounts involve instructions from parents to children; later scribal schools were established which taught not only writing, but also wisdom (Curnow, 2010; Kugel, 2007).

The oldest center for higher learning was Nalanda University, established in the $5^{\text {th }}$ or $6^{\text {th }}$ century BCE, which is reported to have been visited by Buddha; although destroyed in 1193, plans are now in the works to resurrect it as Nalanda International University (Buncombe, 2010). In the Western lineage, ancient Greek aristocratic families hired "sophists" to teach rhetoric and other important skills to their children. 
Philosophical academies were the first centers for adult education in the west and were specifically designed to teach for wisdom. Schools like Plato's academy (ca. 387 BC, Athens) survived hundreds of years before being closed by the Emperor Justinian I in 529AD.

The first European universities appeared in the $11^{\text {th }}$ and $12^{\text {th }}$ centuries. The University of Bologna was established in the Western world in 1088 and the term "university" was coined at its creation. However, public education did not begin in Europe until the 1500s. The schools were devoted to the ideals of Renaissance humanism, which revived the writings of Greece and Rome as models of the height of human knowledge. The invention of the printing press made books more available, but elementary school attendance was still limited to middle and upper class families; only children of nobles attended the humanist secondary schools.

In 1862, the United Kingdom established a school grants system through which schools received funds based on their students' performance on reading, writing, and arithmetic tests. The Education Act of 1870 later authorized the establishment of public board schools. In the United States, Thomas Paine promoted the idea of free public education in the late 1700 s, but only after the efforts of people like Horace Mann, in 1852, did Massachusetts pass the first laws instating free public education. However, it took until 1918 for all U.S. states to make school attendance compulsory and, despite considerable progress over the last decade, the United Nations Millennium Development Goal of universal primary education for all children by 2015 is unlikely to be met.

\section{The Emergence of Mind and Brain}

It appears that Hippocrates (460 to $380 \mathrm{BCE}$ ) was the first to identify the brain as a source of human sensation, knowledge, and wisdom. Centuries later, the stoic philosophers also considered human experience to be completely embodied, although debates continued in antiquity over whether the heart or the brain was the primary organ of human psychic life.

Renaissance figures revived the classical tradition of direct investigation of nature, including the human brain. Thus, Leonardo da Vinci's sketches of a centenarian brain (1508) and Andreas Vesalius's (1543) anatomical work not only created precise visual records, but they also began to name specific areas of the brain (see Kemp, 1972, 2007). In the next century, scientific groups like the Royal Society of London, who published the first scientific journals, emerged. Among the most complete early 
versions of the brain were Christopher Wren's engravings for Thomas Willis' (1664) Cerebri anatome (The Anatomy of the Brain). Wren (who later designed St. Paul's Cathedral in London) was Willis' assistant and medical artist.

In 1693, John Locke wrote Some Thoughts Concerning Education, a manual on how to guide the child to virtue. Locke's hierarchy of values in the education of a gentleman's son centered around: virtue, wisdom, breeding, and learning. His overall curriculum emphasized starting with the fun of learning plain and simple ideas, and of building on children's existing knowledge of how subjects are interconnected (Aldrich, 1994). However, Locke (1690) set aside the question of how mind relates to brain, granting only that it might have a material substrate. But simply opening the possibility of a material substrate for the soul set the stage for Charles Bonnet. In his 1755 Essay on Psychology (the first book with psychology in the title), Bonnet specifically linked mind, brain and education, but without proposing any educational program.

By the $19^{\text {th }}$ century there were discoveries of specific brain area functions. Broca (1862) and Wernicke (1874) established that most people have two main language areas in their left frontal (Broca) and parietal (Wernicke) lobes. Brodmann (1909) charted the primary visual motor and auditory pathways in the brain and his contemporary, Ramón y Cajal (1911) convincingly showed that the neuron was the basic functional and structural unit in the brain. All of these discoveries led people to consider the relationship between mind, learning, and the brain.

\section{Developmental Psychology as a Precursor to MBE}

William James (1899) spoke at length about the implications of psychology for how to teach young children, concluding,

Thus are your pupils to be saved: first, by the stock of ideas with which you furnish them; second, by the amount of voluntary attention that they can exert in holding to the right ones, however, unpalatable; and, third, by the several habits of acting definitely on these latter to which they have been successfully trained. (p. 127)

Mind and brain were linked through evolutionary psychology by Hall and especially by Baldwin in the late 1800s. Most famously, through what is now called the Baldwin Effect, a proposed mechanism for specific evolutionary selection for general learning ability (Broughton, 1981). The Baldwin Effect basically suggested that when 
learning occurs that is beneficial to the survival of a species, then it alters the conditions of selection and eventually the genes passed on to the future descendants. ${ }^{1}$

Jean Piaget developed the ideas of Baldwin and others like Janet to make an enduring contribution to psychology and education. Throughout his career, Piaget strongly grounded his work in biology and tied it to education as phenotypic adaptation (Piaget, 1980). This began with Piaget's work studying children at the Maison des Petits, a progressive school associated with the Jean-Jacques Rousseau Institute, under Edouard Claparède and Pierre Bovet. From 1921-25 he was Research Director of the Jean-Jacques Rousseau Institute, Geneva, and from 1929-67 Director of the International Bureau of Education in Geneva; from 1932-71 he was also Director of the Institute of Educational Sciences at the University of Geneva. Piaget was also appointed the president of the Swiss Commission UNESCO.

Piaget's research most famously identified four stages of cognitive development (sensory-motor stage, preoperational period, concrete operational stage, and formal operational stage), but also proposed adapting these to specific educational settings, along with a biological explanation for how they were instantiated (Piaget, 1970; Smith, 2000).

Another key contributor to the MBE science discipline was Lev Vygotsky, whose ideas of cultural mediation and internalization as related to an individual's "inner speech" are still being debated today. Together with his collaborators, especially Alexander Luria, Vygotsky developed a cultural-historical psychology that also aimed to integrate studies of mind, brain, and education within a developmental framework. Vygotsky's work was important for special education in Russia at that time and he himself worked as a teacher with children with special needs early in his career. His ideas were adapted into curricula structure for school-age children by Vasili Davydov (Davydov, 1995; Yasnitsky, in press).

The approaches of Piaget and Vygotsky are combined in Kurt Fischer's Skill theory, a global theory of human development as a dynamic system that is at the forefront of current work in Mind, Brain, and Education (Fischer \& Bidell, 2006; Stein \& Fischer, 2011).

\section{The Emergence of Mind, Brain, and Education}

In his influential book, "The Organization of Behavior" (1949), Hebb proposed his famous Hebbian synapse rule: Neurons that fire together, wire together, 
explaining the mechanism of classical conditioning, and the associative learning that results when a neutral stimulus is associated with a conditioned stimulus, an associative learning concept first proposed by Aristotle that was to become a core idea in the emerging discipline of MBE.

In 1978 we saw the publication of "Brain Research and Learning" (Claycomb, 1978) by the National Education Association, and of Chall and Mirsky's "Education and the Brain." Both were well-researched efforts to integrate neuroscience and education. Tokuhama-Espinosa (2011) noted that two popular books for educators were also published around this time, Howard Gardner's "Frames of Mind" (1983) and Leslie Hart's "Human Brain, Human Learning" (1983). They were influential in that they sparked a new interest among teachers in the connection between learning and the brain.

Between 1973 and 1979 educational neuropsychology, another forerunner to Mind, Brain, and Education Science (MBE), came to the fore and Gazzaniga proposed incorporating functional neuroscience into teaching in his book, "Neuropsychology: Handbook of Behavioral Neurobiology." Michael Posner also proposed integrating the neurosciences and psychology to improve our understanding of learning.

In 1988, Gerhard Preiss, professor of Didactics at the University of Fribourg, proposed a new discipline that would combine the study of brain processes with that of pedagogy and didactics in order to optimize human learning. This is an approach that still has adherents (for example, see Sabitzer, 2011)

Recently, the emerging field of MBE science has provided an umbrella for research in neuropsychology and neurodidactics. There are two main reasons for this: MBE science studies teaching, not just learning, and the very term "educational neuropsychology" or neurodidactics implies that education and neuroscience are subfields of psychology or didactics, whereas MBE science does not (Tokuhama-Espinosa, 2011).

\section{The Birth of MBE as a Discipline}

MBE as a discipline emerged from several sources in different nations at about the same time. The Decade of the Brain (1990-1999) spurred the development of many new findings and myriad theories about the brain and learning. These were of two basic types: modular, domain-specific theories, which explained the neural mechanisms of skills such as reading, and mathematics, and abilities such as attention 
and memory and global theories of learning which explained how to optimize brain learning in general. At this time, Kurt Fischer and others extolled the value of neuroscience research in education and began to envision an independent field of MBE.

There was an increasing call for bidirectional collaborations between educational psychology and neuroscience and the early 1990s saw more international and interdisciplinary cooperation. In addition, several high-quality teaching interventions, based on neuroscientific research and proven in the lab, appeared. For example, new neuroscientifically based reading curricula, like RAVE-O (retrieval, automaticity, vocabulary, engagement with language, orthography) and Fast ForWord were developed and were being successfully applied in the classroom (Tokuhama-Espinosa, 2011).

In addition, by the early 1990s, early attempts by scientists to produce teacher-friendly information had accelerated, and experimental psychologist Paula Tallal and neurophysiologist Michael Merzenich organized brain-based conferences for educators through their Scientific Learning Corporation.

An important leader in this movement was the Organization for Economic Co-operation and Development (OECD), which held three international conferences_in New York (2000), Granada, Spain (2001), and Tokyo (2001)—that aimed to synthesize ideas and propose research agendas for the emerging discipline that incorporated neuroscience, psychology, and education.

In 2004, the International Mind, Brain, and Education Society (IMBES) was created and has held increasingly larger society meetings. The second IMBES conference in May 2009 showed membership is steadily on the rise.

In 1999, the first "Learning Brain EXPO" in San Diego gathered over 700 teachers and scientists, attesting to the growing popularity of anything labeled brain-based and the first "Learning \& the Brain Conference" at Harvard University and MIT, in 1997, fostered teacher-neuroscientist encounters. The 26 th conference in this series (in May 2010) drew over 2,000 people, mostly educators, showing an ever-deepening concern by learning institutions to incorporate neuroscientific research and knowledge into teacher education.

Coincidently, at the end of the 1990s there was an increase in pedagogical rethinking, including attempts to unite teachers around a set of accepted "best-practice principles" in teaching elements and curriculum/lesson planning, and in 1998, the Education Commission of the United States published a consideration of how 
neuroscience could have educational policy implications. Recently, books with "mind, brain, and education" label in their titles have begun to be published, for example, "The New Science of Teaching and Learning: Using the Best of Mind, Brain, and Education Science in the Classroom" (Tokuhama-Espinosa, 2010) and "The Developmental Relations Between Mind, Brain and Education: Essays in Honor of Robbie Case" (Ferrari \& Vuletic, 2010). Furthermore, in an effort to develop coherence among the research findings from these diverse but connected disciplines, a new journal called "Mind, Brain, and Education" produced by the International Mind, Brain \& Education Society has been developed.

\section{Institutional Development of MBE Programs}

Dartmouth College's doctorate program in psychological and brain science began in 1968, and Dartmouth's undergraduate educational degree in educational neuroscience was founded in 1990. The first dissertation on MBE science was by O'Dell (1981), called, “Neuroeducation: Brain Compatible Learning Strategies." In 1988, the Brain, Neurosciences, and Education Special Interest Group (SIG) of the American Educational Research Association (AERA) was formed out of the Psychophysiology and Education SIG, the oldest U.S. organizational entity specifically linking research in the neurosciences and education (Tokuhama-Espinosa, 2011).

But at the end of the 1990s, although teacher interest in the brain grew, few professional programs in universities offered courses in this discipline, and thus popular-press books about brain-based learning flourished to fill the void. One of the best-selling books of all time aimed at teachers, Jensen's (1998) "Teaching With the Brain in Mind" was published, in its first edition, at this time.

In 1997, Kurt Fischer and colleagues at Harvard developed a new and innovative course called "Mind, Brain, and Education" and after several years of planning (1997-2001) Harvard University launched its Master's Program in Mind, Brain, and Education in 2001-2002. Other programs available in MBE science by 2005 included those at the University of Texas at Arlington, the University of Southern California, as well as a host of international programs that also appeared around this time.

Other institutions are also beginning to explore the possibilities. The Ontario Institute for Studies in Education of the University of Toronto (OISE/UT) hosts a large Initial Teacher Education (ITE) Program and a graduate (MA and PhD) neuroscience research program. In 2007, a new elective course for teacher education candidates called "The Adolescent Brain: Implications for Instruction" was developed and the first 
graduate course, "Neuroscience and Education," followed in 2008. Currently, funding has been obtained to develop a website featuring new developments and research in neuroscience and education for educators and policy makers (McBride \& Ferrari, in preparation).

\section{Part 2: Implementing MBE}

\section{The Promise and the Controversy}

Currently cognitive neuroscience is making rapid strides in areas highly relevant to education. New research on the development of the prefrontal cortex has led to instructional strategies that support and scaffold students' executive functions (Giedd \& Lenroot, 2006; Steinberg, 2007; Van Leijenhorst et al., 2010) while research on changes in circadian rhythm occurring at puberty is relevant not only to teachers but also to parents and policy makers (Beebe, Fallone, Neha Godiwala, \& Flanigan, 2008). In the same vein there is also significant new neurobiological research emerging on reading, dyslexia, mathematics instruction, dyscalculia, autism spectrum disorders, emotional and behavioral disorders, ADHD and learning and memory (Ansari, 2008; Baron-Cohen, Knickmeyer, \& Belmonte, 2005; Immordino-Yang \& Damasio, 2007; Narhi, Lehto-Salo, Ahonen, \& Marttunen, 2010; Shaw et al., 2007; Shaywitz \& Shaywitz, 2008).

It is becoming clear, that although the field of MBE is still in its infancy, knowledge of neuroscience can have a powerful effect on teaching practice. As a result educators are becoming increasingly interested in neuroscience and are motivated to incorporate new research findings into their practice (Goswami, 2006). Indeed, from the early days of psychology as a discipline, teachers have been interested in the new biologically based psychology.

However, in the past as well as in the present, there is controversy. Not everyone is convinced that neuroscience can or should support and inform education. In his "Talks to Teachers," William James (1899) famously said,

You make a great, very great mistake, if you think that psychology, being the science of the mind's laws, is something from which you can deduce definite programmes and schemes and methods of instruction for immediate schoolroom use. Psychology is a science, and teaching is an art; and sciences never generate arts directly out of themselves. (p. 23) 
More recently, John T. Bruer's influential paper, "Education and the Brain: A Bridge Too Far" (1997), challenged the educational relevance of research in neuroscience. Educators supporting Bruer (1997) have argued that teachers cannot translate neuroscience research directly into practice and propose instead that teachers should embrace cognitive psychology to better understand learning.

There is also the difficulty of convincing educators and policy makers of the value of research. Although education has a tendency to quickly adopt new ideas, decisions are usually made without the benefit of any research evidence as to their efficacy or usefulness (Hempenstall, 2006; Marshall, 1993). Maggs and White (1982) stated: "Few professionals are more steeped in mythology and less open to empirical findings than are teachers" (p. 131). Hempenstall (2006) found this to still be true, noting that Carnine (2000) found that education as a profession still ignores research that supports effective practices. In addition, Cooper, Levin, and Campbell (2009) found that despite recognizing that research should inform practice, interventions to increase the use of research evidence, particularly in high schools, is still modest at best.

Even when evidence-based programs are successful, educators may not adopt them. In an implementation study of an evidence-based program, Woodward and Gersten (1992) found that although achievement growth for the students was dramatic, and participating teachers were extremely enthusiastic about the program, one year later only two of the original seven teachers were still using the program. Carnine (2000) also found that when research results conflicted with educators' beliefs and ideology in studies such as Project Follow Through, educators and administrators ignored the findings.

\section{Neuromyths}

Although the promise of neuroscience is exciting there also needs to be caution. Goswami (2006) found that, as a result of educators' interest in neuroscience, teachers and school boards are being bombarded with books, courses, and educational packages that encourage them to create "brain-based classrooms" and to use "brain-based curriculum and instruction." Unfortunately, many of these programs are based on oversimplifications of research findings in neuroscience while others are based on myths about the brain. For example, the myth of left- and right-brained learners - an overgeneralization of hemispheric specialization, the myth of the brainbased classroom - an overgeneralization of research on the effect of stress on brain functioning and the myth that there are layers of the brain that match layers of the 
curriculum. There are also many commercial products being developed which are based not only on myths, but also on misinterpretations of research findings such as the concept of brain neuroplasticity. Teachers and schools are often told that they need to invest in expensive software programs that can rewire the brain, "cure" learning problems and improve academic performance (Blakemore \& Frith, 2005; Geake, 2008).

These myths have developed, in part, because research findings from so many disciplines (among them neuroscience, genetics, physiology, and cognitive psychology) have implications for educational practice. The challenge then is how to translate this complex research into educational practice without losing the integrity of that research, while also making it accessible, comprehensible, and relevant to educators (Purdy \& Morrison, 2009).

\section{Bridging the Gap: Teaching for Wisdom vs. Information}

Gregorian (2007) states that one of modern society's greatest challenges is how to distinguish between information and real knowledge, and further how to transform such knowledge into wisdom. He goes on to say that, given the current overload of information and knowledge, it is the responsibility of educators to teach students how to recognize and use knowledge that is relevant, reliable, and useful.

This is not an easy task, particularly in the field of neuroscience, where much of the research information is technical in nature and difficult to understand and translate into lay terms that can be understood by educators, parents, and policy makers who may have little or no background in the sciences. However, there is now an emerging field called knowledge mobilization (KM), designed to address the research-practice gap. Knowledge mobilization is now recognized as being a key ingredient of all research across disciplines and countries (Cooper et al., 2009).

In addition, "evidence-based decision making" (EBDM) and evidence-informed policy and practice have become top priorities internationally (Davies, Nutley, \& Smith, 2000; Nutley, Walter, \& Davies, 2007).

In 2002, the U.S. Department of Education established the Institute of Education Sciences (IES) to support a more evidence-based approach to education and in Canada, the Canadian Council on Learning (CCL) was developed to support and promote evidence-based decisions about learning. In September 2005, CCL launched "The $21^{\text {st }}$ Century Learning Initiative." One of its goals is to "facilitate the development 
of new approaches to learning that draw upon the most current insights into the human brain" (Canadian Council of Learning).

In order to bridge the research-practice gap, Goswami (2006) suggests that neuroscientists and researchers must speak directly to teachers. There are now a growing number of reliable organizations that actively support this kind of endeavor using technology and the Internet. For example, The Society for Neuroscience (www.sfn.org/) and the Dana Foundation (www.dana.org/resources/brainweb/) among others, have excellent vetted websites. In addition, many universities have also developed informative and reliable websites containing neuroscientific information that is not only relevant, reliable, and useful but that has also been transformed into a format easily understood by educators. As previously mentioned, the authors have just received funding to develop such a website at the University of Toronto.

\section{The Power of Neuroscience}

Research shows that neuroimages such as MRIs are persuasive to both educators and to the public (Weisberg, Keil, Goodstein, Rawson, \& Gray, 2008). Feigenson (2006) hypothesized that neuroimages reduce psychosocial complexities to features of the brain that can be directly viewed. When faced with complex, unfamiliar information, individuals tend to use a reductionist structure to reduce psychological phenomena to their lower level neuroscientific counterparts (Weisberg et al., 2008). In addition, neuroscience is associated with powerful visual imagery, which tends to render scientific claims more convincing. This has far-reaching implications for both teacher education and professional development.

It appears that the introduction of neuroscience into an Initial Teacher Education Program can support and facilitate the transfer of neuroscientific knowledge into best practices in the classroom. It was found that over $90 \%$ of 95 new teachers who had taken a course on the adolescent brain stated that their knowledge of neuroscience research had significantly impacted their classroom practice (McBride \& Todd, 2008; McBride \& Pomeroy, 2009). Research on learning has shown that it is only when the learner understands the underlying principles that knowledge can be applied successfully (Bransford, Brown, \& Cocking, 1999). As early as 1693, John Locke in "Some Thoughts Concerning Education" proposed that individuals gain knowledge best when they gradually combine simple ideas into more complex ones.

Students in a Bachelor of Education (B. Ed.) teacher education program reported that their knowledge of the neural basis of brain functioning allowed them 
to apply underlying processes to their teaching. One could hypothesize that their knowledge of the adolescent brain provided a cohesive conceptual framework within which they could frame the purpose and use of specific instructional strategies. For example, an understanding of the synaptic exuberance and pruning that occurs during adolescence in the prefrontal cortex gave students a rationale for the use of scaffolding. One said, "For the first time I really understood why scaffolding was necessary and I used it a lot during practicum" (Anonymous survey, 2008). Another student said, "I was much more patient because I understood what was happening to my students as a result of the physical and neurobiological changes they were undergoing" (Anonymous survey, 2009).

However, although the teachers reported that a knowledge of neuroscience had significantly impacted their practice they found it difficult to articulate how this had happened. Cooper and Levin (2010) state that research use can occur in many different ways and over a long period of time and can be very difficult to track and measure. More research is needed to identify how and why neuroscientific knowledge impacts practice and policy.

\section{Conclusion}

The time has come for Mind, Brain, and Education to be fully recognized as a science, with the potential to have a powerful impact on educational policy and practice. Educators and school boards are increasingly coming under media scrutiny and increased pressure to improve educational outcomes at a time when educators, policy makers, and the public have become fascinated with "brain research." At the same time, governments and policy makers are promoting and supporting Evidence-Based Decision Making and Knowledge Transformation. These are ideal conditions for the growth of Mind, Brain and Education. However, while there has been significant progress in developing Mind, Brain, and Education as a science, there is still much important work to be done to make neuroscientific findings accessible, comprehensible, and relevant to educators, policy makers, and parents. While teachers are eager to use the latest neuroscientific evidence to inform their practice, we must be careful to guard against "neuromyths" and "fads" by continuing to meet the challenge of retaining the integrity of the research while transforming the findings into useful, relevant, and comprehensible knowledge. We also need to continue to have neuroscience researchers and educators collaborate to develop Mind, Brain, and Education programs and courses that can transform new neuroscientific research into a format that can 
be applied in educational settings. Mind, Brain, and Education is a science that shows great promise. It can, and should, continue to be fruitfully pursued in the future as ever more evidence emerges about the brain that is of great relevance to education.

\section{Notes}

1. This theory had profound influence on the belief that both biology and experience mutually impact learning outcomes. For example, in her eloquent book, Proust and the Squid, Maryanne Wolf (2007) illustrates how reading has changed the human brain through dramatic evolutionary processes, a concept that is reinforced by Stanislaus Dehaene's (2009) belief in neuronal recycling, or the reuse of evolutionarily older areas of the brain for new needs, such as reading, which has only been required for about the past 5000 years.

\section{References}

Aldrich, R. (1994). John Locke. PROSPECTS: the quarterly review of education, $24,(1 / 2)$, 61-76.

Ansari, D. (2008). Effects of development and enculturation on number representation in the brain. Nature Reviews Neuroscience, 9, 278-291.

Baron-Cohen, S., Knickmeyer, R.C., \& Belmonte, M.K. (2005). Sex differences in the brain: Implications for explaining autism. Science, 310, 819-823.

Beebe, D.W., Fallone, G., Neha Godiwala, N., \& Flanigan, M. (2008). Feasibility and behavioral effects of an at-home multi-night sleep restriction protocol for adolescents. Journal of Child Psychology and Psychiatry, 49(9), 915-923.

Blakemore, S., \& Frith, U. (2005). The learning brain: Lessons for education. Oxford, UK: Blackwell.

Bonnet, C. (1755). Essai de psychologie; ou considérations sur les opérations de l'ame, sur
I'habitude et sur l'éducation. Auxquelles on a ajouté des principes philosophiques sur la cause première et sur son effet. London.

Bransford, J. D., Brown, A. L., \& Cocking, R. R. (Eds.), (1999). How people learn: Brain, mind, experience, and school. National Research Council. National Academy Press: Washington, D.C.

Broca, P.P. (1862). Mémoire sur le craniographe et sur quelquesunes de ses applications. In Mémoires de la Société d'anthropologie de Paris. Série 1. Georges Masson, Paris, 349-378.

Brodmann, K. (1909/1994). Brodmann's 'Localisation in the Cerebral Cortex'. SmithGordon, London, UK.

Broughton, JM (1981). The genetic psychology of James Mark Baldwin. American Psychologist, 36, 396-407.

Bruer, J. (1997). Education and the brain: A bridge too far. Educational Researcher, 4-16. 
Buncombe, A. (August, 2010). Oldest university on earth is reborn after 800 years. Independent (Asia). Retrieved June 30, 2001, from http://www.independent.co.uk/news/ world/asia/oldest-university-on-earth-isreborn-after-800-years-2042518.html.

Canadian Council of Learning (2011). $21^{\text {st }}$ century learning initiative (Canada). Retrieved November 4, 2011, from http://www.ccl-cca. $\mathrm{ca} / \mathrm{ccl} /$ aboutccl/21stCentury.html

Carnine, D. (2000). Why education experts resist effective practices (and what it would take to make education more like medicine). Washington, DC: Fordham Foundation. Retrieved October 20, 2011, from http://www. sc-boces.org/english/IMC/Focus/DirectInstruction-carnine_article.pdf

Chall, J. S. \& Mirsky, A. F. (Eds) (1978). Education and the brain. Chicago: University of Chicago Press.

Claycomb, M. (1978). Brain research and learning: a position paper. Washington, D.C: National Education Association.

Cooper, A. \& Levin, B. (2010). Some Canadian contributions to understanding knowledge mobilization. Evidence \& Policy, 6(3), 351-369.

Cooper, A., Levin, B., \& Campbell, C. (2009). The growing (but still limited) importance of evidence in education policy and practice. Journal of Educational Change, 10, 159-171.

Curnow, T. (2010). Wisdom in the ancient world. London: Duckworth.

Davies, H., Nutley, S., \& Smith, P. (2000). What works? Evidence-based policy and practice in public services. Bristol: Policy Press.

Davydov, V.V. (1995). The influence of L.S. Vygotski on education. Theory, research, and practice. Educational Researcher, 24(3), 12-21.

Dehaene, S. (2009). Reading in the brain. New York: Penguin Viking.

Feigenson, N. (2006). Brain imaging and courtroom evidence: On the admissibility and persuasiveness of fMRI. International Journal of Law in Context, 2, 233-255.

Ferrari, M., \& Vuletic, L. (2010). The developmental relations between mind, brain and education: Essays in honor of Robbie Case. Amsterdam, NL: Springer.
Fischer, K. W., \& Bidell, T. R. (2006). Dynamic development of action, thought, and emotion. In R. M. Lerner (Ed.) \& W. Damon (Series Ed.), Handbook of child psychology: Vol. 1. Theoretical models of human development ( $6^{\text {th }}$ ed.). New York: Wiley.

Gazzaniga, M.S. (ed). (1979). Handbook of behavioral neurobiology, vol. 2: Neuropsychology. New York: Plenum Press.

Geake, J. (2008). Neuromythologies in education. Educational Research, 50(2), 123-133

Giedd, J., \& Lenroot, R. K. (2006). Brain development in children and adolescents: Insights from anatomical magnetic resonance imaging. Neuroscience and Behavioral Reviews, 30, 718-729.

Goswami, U. (2006). Neuroscience and education: from research to practice? Nature reviews neuroscience. Retrieved May 2008, from http://www.nature.com/reviews/neuro

Gregorian, V. (2007). A sense of elsewhere. American Libraries, 38(10), 46-48.

Hebb, D.O. (1949). The organization of behavior. New York: Wiley.

Hempenstall, K. (2006). What does evidencebased practice in education mean? Australian Journal of Learning Disabilities, 11(2), 29-38.

Immordino-Yang, M., \& Damasio, A. (2007). We feel, therefore we learn: The relevance of affective and social neuroscience to education. Mind, Brain, and Education, 1, 3-10.

James, W. (1899). Talks to teachers on psychology and to students on some of life's ideals. New York: Henry Holt.

Jensen, E. (1998). Teaching with the brain in mind. Association for Supervision and Curriculum Development, Alexandria, VA (revised, 2005).

Kemp, M. (1972). Dissection and divinity in Leonardo's late anatomies. Journal of the Warburg and Courtauld Institutes, XXXV, 200-225.

Kemp, M. (2007) Leonardo da Vinci: Experience, experiment, and design. London: V\&A Publications.

Kugel, J. (2007). How to read the Bible: A guide to Scripture, then and now. New York: Free Press. 
Locke, J. (1690). An essay concerning human understanding. London.

Locke, J. (1693). Some thoughts concerning education. London: Printed for A. and J. Churchill.

Maggs, A., \& White, R. (1982). The educational psychologist: Facing a new era. Psychology in the Schools, 19, 129-134.

Marshall, J. (1993). Why Johnny can't teach. Reason, 25(7), 102-106.

McBride, H.E.A., \& Pomeroy, M. (2009). Neuroscience: A powerful influence on educational practice. Paper presented at the Second Biennial International Mind, Brain and Education Society Conference, Philadelphia.

McBride, H.E.A., \& Todd, R. (2008). From theory to practice: Introducing neuroscience into a teacher education program. Paper presented at The Jean Piaget Society's $38^{\text {th }}$ Annual Meeting, Quebec City, Quebec.

Narhi, V., Lehto-Salo, P., Ahonen, T., \& Marttunen, M. (2010). Neuropsychological subgroups of adolescents with conduct disorder. Scandinavian Journal of Psychology, 51, 278-284.

Nutley, S., Walter, I., \& Davies, H. (2007). Using evidence: How research can inform public services. Bristol: Policy Press.

Piaget, J. (1970). Piaget's theory. In P. H. Mussen (Ed.), Carmichael's manual of child psychology (3rd ed., Vol. 1, pp. 703-723). New York: Wiley.

Piaget, J. (1980). Adaptation and intelligence: Organic selection and phenocopy. Chicago: University of Chicago Press.

Purdy, N. \& Morrison, H. (2009). Cognitive neuroscience and education: unravelling the confusion. Oxford Review of Education, 35(1), 99-109.

Ramon y Cajal, S. (1911). Histologie du Systeme Nerveux de l'Homme et des Vertebres. Paris. English translation: Histology of the nervous system of man and vertebrates (trans. Swanson, N. \& Swanson, L. W.), Oxford University Press, 1995.

Sabitzer, B. (2011). Neurodidactics: Brain-based Ideas for ICT and Computer Science Education. The International Journal of Learning, 18(2), 167-178.
Saurez-Orozco, M., \& Sattin-Bajaj, C. (Eds.), (2010). Educating the whole child for the whole world. New York: New York University Press.

Shaw, P., Eckstrand, K., Sharp, W., Blumenthal, J., Lerch, J.P., Greenstein, D., et al. (2007). Attention-deficit/hyperactivity disorder is characterized by a delay in cortical maturation. Proceedings of the National Academy of Science, 104(49), 19649-19654.

Shaywitz, E., \& Shaywitz, A. (2008). Paying attention to reading. The neurobiology of reading and dyslexia. Development and Psychopathology, 20(4), 1329-1349.

Smith, L. (2000). A brief biography of Piaget. Jean Piaget Society Website (http://www.piag et.org/aboutPiaget.html).

Stein, Z., \& Fischer, K.W. (2011). Directions for mind, brain, and education: Methods, models, and morality. Educational philosophy and theory. Educational Philosophy and Theory, 43, 56-66.

Steinberg, L. (2007). Risk taking in adolescence: New perspectives from brain and behavioral science. Current Directions in Psychological Science, 16, 55-59.

Tokuhama-Espinosa, T. (2010). The new science of teaching and learning: Using the best of mind, brain, and education science in the classroom. New York: Columbia University Teachers College Press.

Tokuhama-Espinosa, T. (2011). A brief history of the science of learning: Part 1 (3500 B.C.E.-1970 C.E.) \& Part 2 (1970-the present). New Horizons for Learning, 9(1). Published on line (http://education.jhu.edu/ newhorizons/Journals/Winter2011/).

Van Leijenhorst, L., Moor, B.G., Zdeňa A., de Macks, O., Serge, A.R.B., Rombouts, P., et al. (2010). Adolescent risky decisionmaking: Neurocognitive development of reward and control regions. Neurolmage, 51, 345-355.

Van Steenbergen, H., Band, G.P.H., \& Hommel, B. (2009). Reward counteracts conflict adaptation. Evidence for a role of affect in executive control. Psychological Science, 20(12), 1473-1477. 
Vesalius, A. (1543). De humani corporis fabrica. [On the fabric of the human body, translated by W. F. Richardson and J. B. Carman. 5 vols. San Francisco and Novato: Norman Publishing, 1998-2009].

Weisberg, D. S., Keil, C., Goodstein, J., Rawson, E., \& Gray, J. R. (2008). The seductive allure of neuroscience explanations. Journal of Cognitive Neuroscience, 20(3), 470-477.

Wernicke, K. (1874/1977). The aphasia symptom complex: A psychological study on an anatomic basis. Translated by Eggert, G. H. (1977). Wernicke's works on aphasia: A sourcebook and review. Mouton Publishers: The Hague.

Willis, T. (1664). Cerebri anatome. Translated by Samuel Pordage in 1681 as "The anatomy of the brain," the translation of which is reprinted in several editions. The McGill University Press edition (1965) and the Classics of Medicine Library edition (1978), in addition to being facsimile editions of Pordage both also include his useful "Table of all the hard words derived from the Greek and Latin, of all Terms of Art and other words not vulgarly received."

Wolf, M. (2007). Proust and the squid: The story and science of the reading brain. New York: Harper.

Woodward, J., \& Gersten, R. (1992). Innovative technology for secondary learning disabled students: A multi-faceted study of implementation. Exceptional Children, 58(5), 407-421.

Yasnitsky, A. (in press). Lev Vygotsky: Philologist and defectologist: A socio-intellectual biography. In W. Pickren (Ed.). Portraits of pioneers in psychology (volume 7).

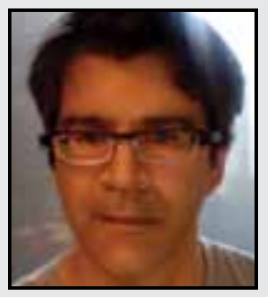

Michel Ferrari teaches psychology at the University of Toronto|OISE. He is leading an international investigation of wisdom involving Canada, USA, India, China, Ukraine, and Serbia. His publications include Developmental Relations among Mind, Brain, and Education: Essays in honor of Robbie Case with Ljiljana Vuletic, (2010), and with Roger Taylor, Epistemology and Science Education: Understanding the evolution vs. intelligent design controversy (2011); with Chandi Fernando, Handbook on Resilience in Children of War (in press).

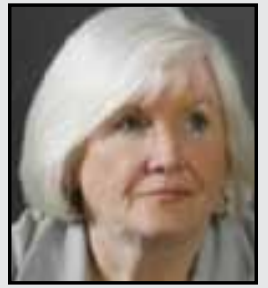

Hazel McBride was a certified teacher prior to obtaining her PhD in cognitive psychology. She currently teaches at The University of Toronto|OISE. She has developed a course called "The Adolescent Brain" for Initial Teacher Education students as well as a graduate course called "Neuroscience and Education." She has also conducted research in the area of neuroscience and education.

\section{LINKTO:}

http://hdap.oise.utoronto.ca 